\title{
ASPEK PERILAKU MANUSIA SEBAGAI MAKHLUK INDIVIDU DAN SOSIAL PADA RUANG TERBUKA PUBLIK
}

\author{
Dedi Hantono* ${ }^{* 1}$, Diananta Pramitasari ${ }^{2}$ \\ *1Universitas Muhammadiyah Jakarta, 2Universitas Gadjah Mada \\ e-mail: *1dedihantono@ftumj.ac.id, ${ }^{2}$ dpramitasari@ugm.ac.id
}

\begin{abstract}
Abstrak_Ruang terbuka publik merupakan elemen kota yang sangat penting kehadirannya dalam kehidupan kota. Sebagai ruang terbuka yang bersifat publik maka berbagai aktivitas dapat dilakukan manusia baik perorangan maupun berkelompok. Karakteristik manusia sebagai makhluk individu sekaligus makhluk sosial menjadi hal yang menarik untuk diteliti bagaimana manusia mempertahankan sifat keprivasian mereka dalam ruang terbuka publik yang dapat diakses siapa saja. Oleh karena itu tujuan dari penelitian ini untuk melihat gambaran bagaimana manusia mengaktualisasikan karakternya sebagai makhluk individu dalam suatu ruang sosial di ruang terbuka publiksehingga manfaat dari penelitian ini diharapkan bisa digunakan para perancang ruang kota dalam memperhatikan kebutuhan karakter manusia sebagai pengguna ruang tersebut. Metode penelitian yang digunakan adalah metode kualitatif dengan melakukan pendekatan kajian literatur yaitu menggunakan beberapa teori dan artikel penelitian yang sesuai yang telah dilakukan. Berdasarkan kajian literatur yang dilakukan ditemukan bahwa karakter manusia sebagai makhluk individu dan makhluk sosial dalam ruang terbuka publikterdapat 2 bentukan ruang yaitu ruang pribadi (personal space) yaitu ruang maya yang berada di sekeliling tubuh masing-masing individu dan teritori (territory) yang dibentuk sesuai dengan kondisi tertentunamunmasih dapat diusik oleh individu lain sehingga pertahanan manusia ini sifatnya tidak masif. Teritori juga dipengaruhi oleh 2 faktor yaitu ekonomi dan budaya.
\end{abstract}

Kata kunci: Arsitektur Perilaku; Ruang Kota; Ruang Terbuka Publik; Ruang Pribadi; Teritori.

\begin{abstract}
Abstrak_Public open space is an element of the city that is very important of its presence in city life. As a public open space, various activities can be carried out by humans, both individuals and groups. The characteristics of humans as individual and also social being; becoming interesting things to be investigated that how humans maintain their privacy in public open spaces that can be accessed by anyone. Therefore the purpose of this study is to gain the description of how humans actualize their characters as individual beings in a social space in public open space so that the benefits of this research are expected to be able to be used by urban space designers in concerning to the human character needs as the space user. The research method used was a qualitative method by conducting a literature study approach, which used several theories and research articles that were appropriate. Based on the literature review, it was found that human characters as individual and social being in public open spaces had 2 spatial forms, namely personal space which was the virtual space available around the body of each individual and territory formed according with certain conditions but can still be disturbed by other individuals so that the human defense is not massive. Territory is also influenced by two factors, namely economy and culture.
\end{abstract}

Keywords: Behavior Architecture; Urban Space; Public Open Space; Personal Space; Territory.

\footnotetext{
${ }^{1}$ Universitas Muhammadiyah Jakarta

${ }^{2}$ Universitas Gadjah Mada
} 


\section{PENDAHULUAN}

Sifat hakiki seorang manusia adalah bahwa selain sebagai makhluk individu juga sekaligus sebagai makhluk sosial. Menurut Effendi (2010) dalam Purwantiasning (2017) individu merupakan penjabaran dari kata "in" dan "divided" yang dapat dimaknai sebagai kesatuan, tidak dapat dipisahkan, dan tidak dapat dibagi-bagi. Artinya bahwa manusia sebagai makhluk individu merupakan satu kesatuan antara aspek jasmani (fisik) dan rohani (psikologis) yang tidak dapat dipisahkan. Sementara itu manusia sebagai makhluk sosial berasal dari kata latin "socius" yang artinya ber-masyarakat yang dalam makna sempit adalah mendahulukan kepentingan bersama atau masyarakat. Sehingga arti dari manusia sebagai makhluk sosial dapat diartikan sebagai makhluk yang hidup bersama dengan manusia lain dan tidak dapat melakukan kegiatannya sendiri tanpa adanya keterlibatan orang lain. Dalam kegiatannya tersebut manusia akan selalu membutuhkan orang lain dan membutuhkan wadah untuk melakukan kegiatan tersebut. Wadah inilah yang kemudian dikenal sebagai ruang berinteraksi bagi individu baik secara individu maupun secara berkelompok (Purwantiasning, 2017).

Selain sebagai makhluk individu, manusia juga merupakan makhluk sosial. Tidak ada satu manusia pun yang dapat hidup tanpa adanya peran dari manusia lainnya. Oleh karena itu selain kebutuhan akan privasi, manusia juga membutuhkan aktivitas sosial antar sesama. Hubungan sosial yang terjalin bisa terjadi pada sesama manusia yang sudah saling mengenal maupun baru pertama kali bertemu dalam kehidupan sehari-hari.

Dalam konteks ruang pribadi seperti rumah tinggal, ruang tidur, ruang kerja, dan lain-lain, maka aktualisasi diri tidak begitu sulit karena ruang-ruang tersebut merupakan ruang privat yang memang diperuntukkan bagi kegiatan yang sifatnya pribadi. Mereka dengan bebas beraktivitas di dalam ruang tersebut dan mengaktualisasikan dirinya sebagai makhluk pribadi (individu).

Sebagai makhluk sosial maka manusia memerlukan interaksi dengan manusia lain. Mereka melakukan aktivitas secara bersama-sama dalam suatu ruang sosial. Interaksi sosial ini biasanya dilakukan di ruang publik dimana siapa saja bisa mengaksesnya. Pada kasus ini manusia menampilkan identitas dirinya sebagai makhluk sosial. Namun selama proses interaksi tersebut, manusia tetap mempertahankan identitas mereka sebagai makhluk individu.

Aspek perilaku manusia dalam kaitannya sebagai makhluk individu sekaligus sebagai makhluk sosial merupakan permasalahan penelitian yang menarik untuk dikaji pada ruang terbuka publik. Bagaimana karakter individu mereka dipertahankan dalam suatu ruang sosial seperti halnya ruang terbuka publik ini. Adapun tujuan penelitian ini ingin mendapatkan gambaran bagaimana manusia mempertahankan karakter individunya dalam suatu ruang sosial. Apakah karakter individu ini selalu mengikuti mereka dalam gerak ruang sosial?

\section{METODE}

Penelitian ini menggunakan metode kualitatif dengan melakukan pendekatan kajian literatur. Literatur yang digunakan adalah sumber primer yaitu tulisan yang berasal dari penulis yang melihat, mengalami, dan mengerjakan sendiri tulisan tersebut. Sumber primer dapat berupa buku catatan, skripsi, laporan akhir penelitian, dan hasil kuesioner/wawancara, dan lain-lain. Untuk mendukung literatur yang sudah ada maka literatur sumber skunder dapat digunakan yaitu kamus, handbooks, textbooks, indeks, dan lain-lain.

Dalam penelitian ada 3 pedoman dalam memilih literatur yang digubakain, diantaranya: relevansi, kemutakhiran, dan adekuasi (Hadi, 1991). Untuk menjaga relevansi dengan penelitian yang dilakukan maka artikel jurnal yang dipilih adalah artikel yang memuat penelitian tentang aspek perilaku manusia pada ruang terbuka publik khususnya dalam konteks sifat manusia sebagai makhluk pribadi sekaligus sebagai mahkluk sosial. Namun tidak menutup kemungkinan dengan 
artikel lainnya sepanjang mendukung kajian tulisan ini. Literatur yang digunakan tidak kurang dari 5 artikel yang masing-masing disampaikan secara tersendiri untuk mendapatkan gambaran yang jelas mengenai perilaku manusia pada ruang terbuka publik. Literatur yang dipilih berasal dari sumber yang masa publikasinya tidak lebih lama dari 10 tahun khususnya untuk literatur sumber primer agar informasi yang didapat sesuai (update) dengan kondisi yang ada sekarang.

Data adalah salah satu bagian dari penelitian. Dalam penelitian literatur data yang didapat kemudian dilakukan pengeditan yaitu pemeriksaan kembali data yang telah dikumpulkan terutama dari segi kelengkapan serta kejelasan dan keselarasan makna antara satu sumber dengan sumber yang lain. Kemudian data-data tersebut disusun dan ditabulasi untuk memudahkan pembacaan dan penganalisaan. Pada akhirnya data-data tersebut dianalisa dan dilakukan pembahasan untuk ditarik suatu kesimpulan yang merupakan jawaban dari rumusan dan pertanyaan penelitian.

\section{HASIL DAN PEMBAHASAN}

\section{A. Manusia dan Ruang}

Manusia mempersepsikan ruang tidak berdiri sendiri melainkan juga dengan lingkungannya. Jika dalam suatu ruang ada manusia lain maka masing-masing mereka akan membuat jarak tertentu yang besarnya tergantung kualitas hubungan antar orang tersebut (Sarwono, 1995).

Hubungan emosional merupakan konsep tentang ruang personal yang mempengaruhi tingkat privasi seseorang yang membentuk ruang personal mereka masing-masing. Konsep ini memenuhi 2 fungsi dasar dari ruang personal, yaitu: proteksi (privasi) dan komunikasi (sosial). Zona kedekatan tergantung dari hubungan antar pribadi dan aktivitas yang dilakukan. Bentuk hal seperti ini disebut proksimik yang terbagi dalam 4 tingkatan kualitas, diantaranya: jarak intim, jarak pribadi, jarak sosial, jarak publik (Halim, 2005) seperti yang terlihat pada Gambar 1 di bawah ini.

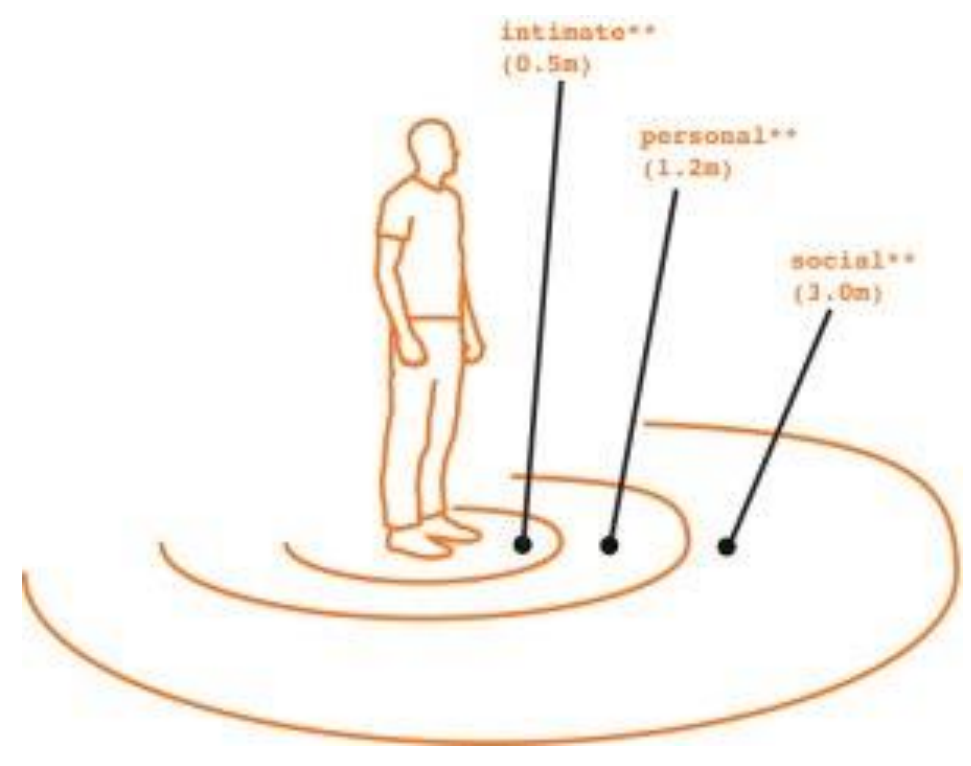

Gambar 1: Zonasi Kedekatan

Sumber: https://winnerfirmansyah.wordpress.com/2010/04/11/privasi-dan-teritorial-manusia/, diakses September 2018 
Manusia hidup dalam waktu maupun ruang dimana antara keduanya saling berinteraksi dan mempengaruhi. Bahkan dalam kondisi tradisional, ruang, waktu, makna, dan komunikasi saling keterkaitan. Hubungan ini dapat berupa hubungan dimensional (antropometri) serta hubungan psikologi dan emosional (proksimik) (Hakim \& Utomo, 2003).

Tabel 1. Proksimik

\begin{tabular}{|c|c|c|}
\hline & Hubungan \& Aktivitas & Kualitas Sensorik \\
\hline $\begin{array}{l}\text { Jarak intim } \\
(0-0,45 \mathrm{~m})\end{array}$ & 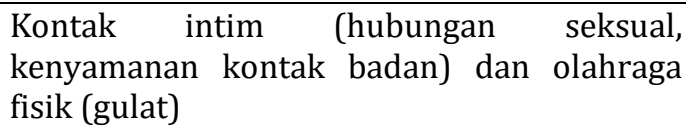 & $\begin{array}{l}\text { Peningkatan kewaspadaan input sensor; } \\
\text { sentyhan mengambil alih vokalisasi verbal } \\
\text { sebagai bentuk komunikasi. }\end{array}$ \\
\hline $\begin{array}{l}\text { Jarak pribadi } \\
(0,45-1,2 \mathrm{~m})\end{array}$ & $\begin{array}{l}\text { Kontak antar teman dekat, juga interaksi } \\
\text { setiap hari dengan kenalan }\end{array}$ & $\begin{array}{l}\text { Input sensor sedikit lebih waspada daripada } \\
\text { jarak intim, pandangan normal dan } \\
\text { menyediakan feedback spesifik; komunikasi } \\
\text { verbal daripada sentuhan. }\end{array}$ \\
\hline
\end{tabular}

Jarak sosial Kontak yang tidak pribadi dan kontak bisnis Input sensor minimal; pandangan kurang $(1,2-3,6 m)$ spesifik daripada jarak pribadi; suara normal (audible 6m) dipertahankan; tidak memungkinkan sentuhan.

\begin{tabular}{|c|c|c|}
\hline $\begin{array}{l}\text { Jarak publik } \\
\qquad>3,6 \mathrm{~m})\end{array}$ & $\begin{array}{l}\text { Kontak formal antara individu (aktor, } \\
\text { politikus) dengan publik }\end{array}$ & $\begin{array}{l}\text { Tidak ada input sensor, tidak ada visual } \\
\text { spesifik }\end{array}$ \\
\hline
\end{tabular}

Sumber: Halim, 2005

Perbedaan individual dalam perilaku spasial juga banyak dipengaruhi oleh faktor-faktor lainnya, seperti: budaya, usia, jenis kelamin, dan lain-lain. Meskipun demikian secara agregatif bahwa jarak-jarak tertentu bisa dipakai pada jenis-jenis hubungan tertentu. Tingkat keagregatan tersebut menurut Chermayeff dan Alexander (1963) dalam Deddy Halim (2005) bisa dilihat dari tingkatan ruang personal menuju ruang publik yang memiliki 6 (enam) spektrum sebagai berikut:

1. Daerah pribadi perorangan, berhubungan dengan satu individu (ruang personal).

2. Daerah pribadi keluarga atau kelompok kecil, berhubungan dengan kelompok (rumah tangga, asrama, dll).

3. Daerah pribadi kelompok besar, berhubungan dengan kelompok sekunder (manajemen pengelolaan privasi atas nama semua penghuni dalam suatu bangunan apartemen.

4. Daerah publik kelompok besar, meliputi interaksi kelompok besar dengan publik (kaki lima dalam suatu linkungan yang dikontrol jam buka-tutupnya dan jalan lingkungan).

5. Daerah semi publik perkotaan, yang diawasi pemerintah atau institusi dengan akses masuk untuk publik sesuai dengan kebutuhan (bank, kantor pos, pelabuhan udara, balai kota).

6. Daerah publik perkotaan, ditandai dengan kepemilikan umum dan akses publik sepenuhnya (taman, mal, dan jalan raya).

Dilihat dari spektrum di atas maka ruang personal bersifat dinamis dengan dimensi yang dapat berubah. Orang akan membutuhkan ruang personal yang lebih besar pada seting publik perkotaan, seperti taman, plaza, dan lain-lain dibandingkan pada daerah semi publik perkotaan. Pada daerah semi publik perkotaan membutuhkan memiliki ruang personal yang lebih besar dibandingkan pada ruang publik, dan begitu seterusnya. Akan terjadi ketegangan dan kegelisahan bila ruang ini dimasuki oleh orang lain apalagi yang belum dikenal(Hadi, 1991).

Sama halnya dengan personal space, untuk menghindari ketegangan dan mempertahankan ruang pribadi maka individu membatasi ruangnya tersebut dalam suatu ruang teritori(Haryadi \& Setiawan, 2014).Namun yang membedakan adalah bahwa ruang personal merupakan ruang maya yang dapat berpindah mengikuti pergerakan individunya sedangkan teritori merupakan tempat yang relatif tetap dan memiliki batasan yang nyata(Sarwono, 1995). 
Aktualitas ruang teritori ini bisa dilakukan dengan berbagai cara, diantaranya: tulisan, penanda, pagar, dan lain-lain. Bentuk dan konsep teritori ini bersifat subjektif sehingga masih bisa diganggu oleh individu lain. Menurut Laurens (2004), pelanggaran teritori dapat diindikasikan dalam bentuk invasi yaitu mengambil kendali atas teritori orang lain. Selain itu, kekerasan juga merupakan pelanggaran teritori yang bertujuan bukan untuk memiliki namun hanya sebatas gangguan. Dan bentuk lainnya, pelanggaran teritori dapat berupa kontaminasi yaitu meninggalkan keburukan pada teritori individu lain, misalnya membuang sampah pada area publik, merusak fasilitas publik, dan lain-lain (Laurens, 2004).

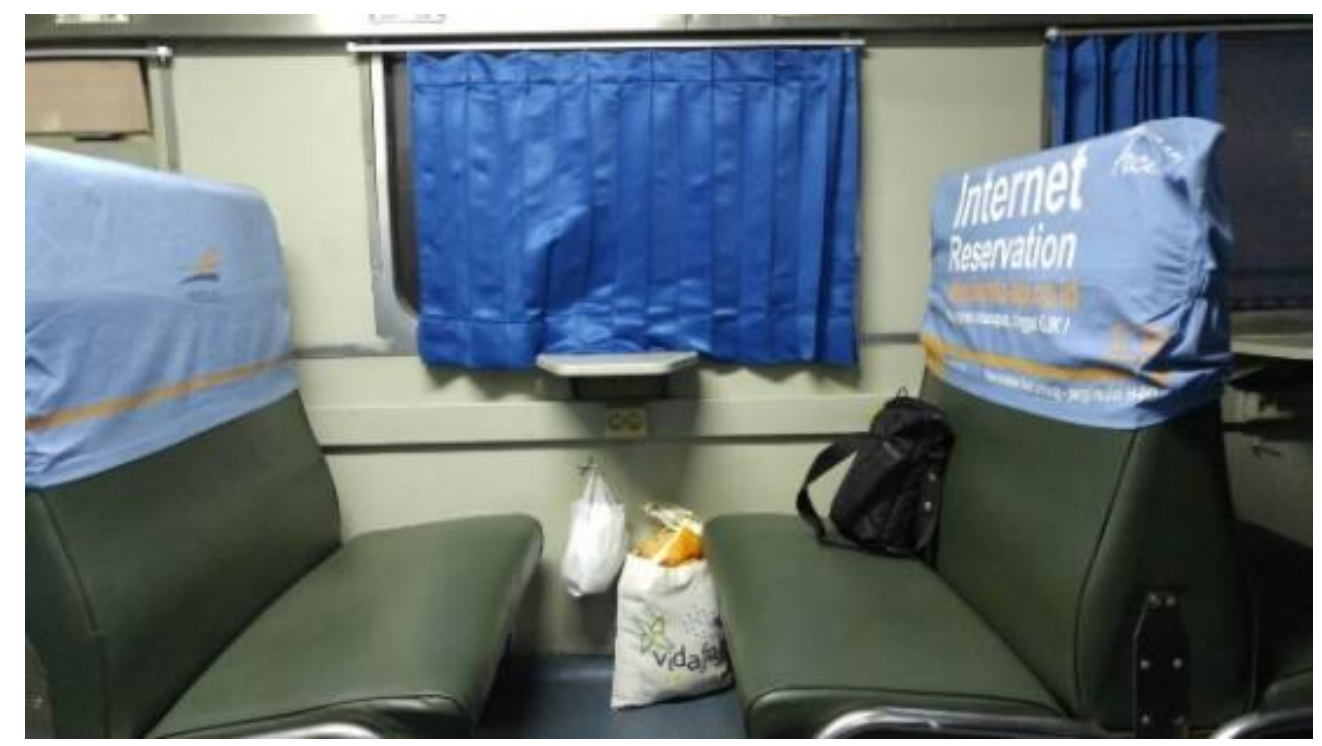

Gambar 2: Meletakkan Barang Pribadi pada Suatu Tempat yang Ditinggalkan Sementara Sebagai Pembentuk Ruang (Teritori)

Sumber: http://atemalem.com/gaya-baru-malam-selatan/, Februari 2018

\section{B. AspekPerilaku Manusia Sebagai Makhluk Individu dan Sosial Pada Ruang Terbuka Publik}

Pola perilaku manusia dalam suatu lingkungan adalah hasil dari proses interaksi manusia dengan lingkungannya yang melibatkan emosional individual dan sosial. Dalam menganalisa terhadap privasi dan kebutuhan sosialnya tersebut diperlukan pendekatan melalui seting perilaku. Konsep ini mengacu pada seting perilaku yang terdiri dari 3 komponen, diantaranya: fisik (desain), sosial (penggunaan), dan budaya. Ketiga hal tersebut bisa ditemui dari beberapa artikel penelitian berikut ini.

Pendekatan penelitian yang dilakukan oleh Al-Bishawi, dkk (2015) dalam perancangan kota lama di kota-kota Arab-Muslim mengenai nilai-nilai Islam tentang privasi perempuan telah diterapkan secara baku. Pada umumnya kaum perempuan memiliki nilai dan kebutuhan khusus akan privasi, keamanan, dan kenyamanan.

Penempatan jendela dan pintu dibuat agar perempuan dapat mengamati jalan tanpa mereka dapat dilihat. Adanya gang-gang buntu yang biasanya digunakan oleh perempuan untuk dapat mengakses pasar atau fasilitas publik sehingga mereka dapat leluasa berjalan tanpa dapat bebas terlihat. Ruang publik mudah diakses oleh perempuan namun tidak halnya dengan ruang publik yang berfungsi sebagai restoran, fasilitas olah raga, dan tamanyang memiliki akses terbatas atau bahkan tidak sama sekali. Selain itu perbedaan waktu penggunaan fasilitas publik juga memiliki peranan penting dalam pemisahan gender tersebut.

Privasi tetap terjaga dengan menggunakan desain pintu dan jendela yang tidak saling berhadapan dan sangat tersembunyi, perbedaan level jalan dan lantai, jendela yang ditinggikan dan tertutup, ruang transisi antar jalan utama dengan jalan buntu, hubungan sosial hanya 
antara pengguna yang memiliki hubungan kekerabatan, perilaku yang terkait dengan agama dan ruang-ruang tertentu yang ditetapkan untuk perempuan saja (melalui tanda-tanda tertulis) atau terbatas pada penggunaan pejalan kaki. Privasi perempuan dicapai terutama melalui komponen sosial dan budaya, yang pada gilirannya mempengaruhi komponen fisik ruang publik.Hasilnya menunjukkan bahwa kebutuhan privasi perempuan tetap terpenuhi pada lingkungan yang bersifat publik dengan berbagai usaha(Al-Bishawi, Ghadban, \& Jørgensen, 2015).

Konsep teritorialitas pada ruang terbuka publik khususnya oleh Pedagang Kaki Lima (PKL) menjadi bagian permasalahan setiap kota di Indonesia sebagaimana dalam penelitian yang dilakukan oleh Kurniadi, dkk (2012). Teritorial PKL tersebut muncul disebabkan adanya motif dan kebutuhan dari PKL itu sendiri untuk berjualan di lokasi yang dianggap strategis di ruang publik dengan membangun 'produk fisik' berupa kios. Kios-kios terbentuk dengan dipengaruhi kebutuhan PKL dalam suatu display, menyimpan barang dagangan, perlindungan dari iklim dan dengan biaya yang murah atau bahkan tidak dengan menggunakan biaya. Modal yang kecil mendorong penggunaan material seadanya, agar pengeluaran dapat ditekan sekecil mungkin.

Pemilik Toko memiliki teritori formal sehingga tidak bisa diganggu oleh individu lain karena dimiliki secara legal dan sesuai dengan peraturan yang berlaku. Namun begitupun pemilik toko melakukan dua macam usaha membentuk ruang teritori. Pertama, pemilik toko melakukan penandaan dengan meletakkan barang dagangan untuk membentuk teritori yang terbentuk akibat motif dan kebutuhan pemilik toko agar display barang dagangan dapat dengan mudah dilihat oleh pembeli dan menambah luas area display. Dengan terbentuknya batasan-batasan fisik di sidewalk toko membentuk teritorialitas yang non-formal dari pemilik toko di area yang sesungguhnya adalah domain publik. Kedua, pemilik toko mempertegas batasan teritori anyar pemilik toko lainnya. Dengan demikian, ada unsur laten diluar manifes area itu sebagai jalur pejalan kaki sebagai suatu 'teritori non-formal'.

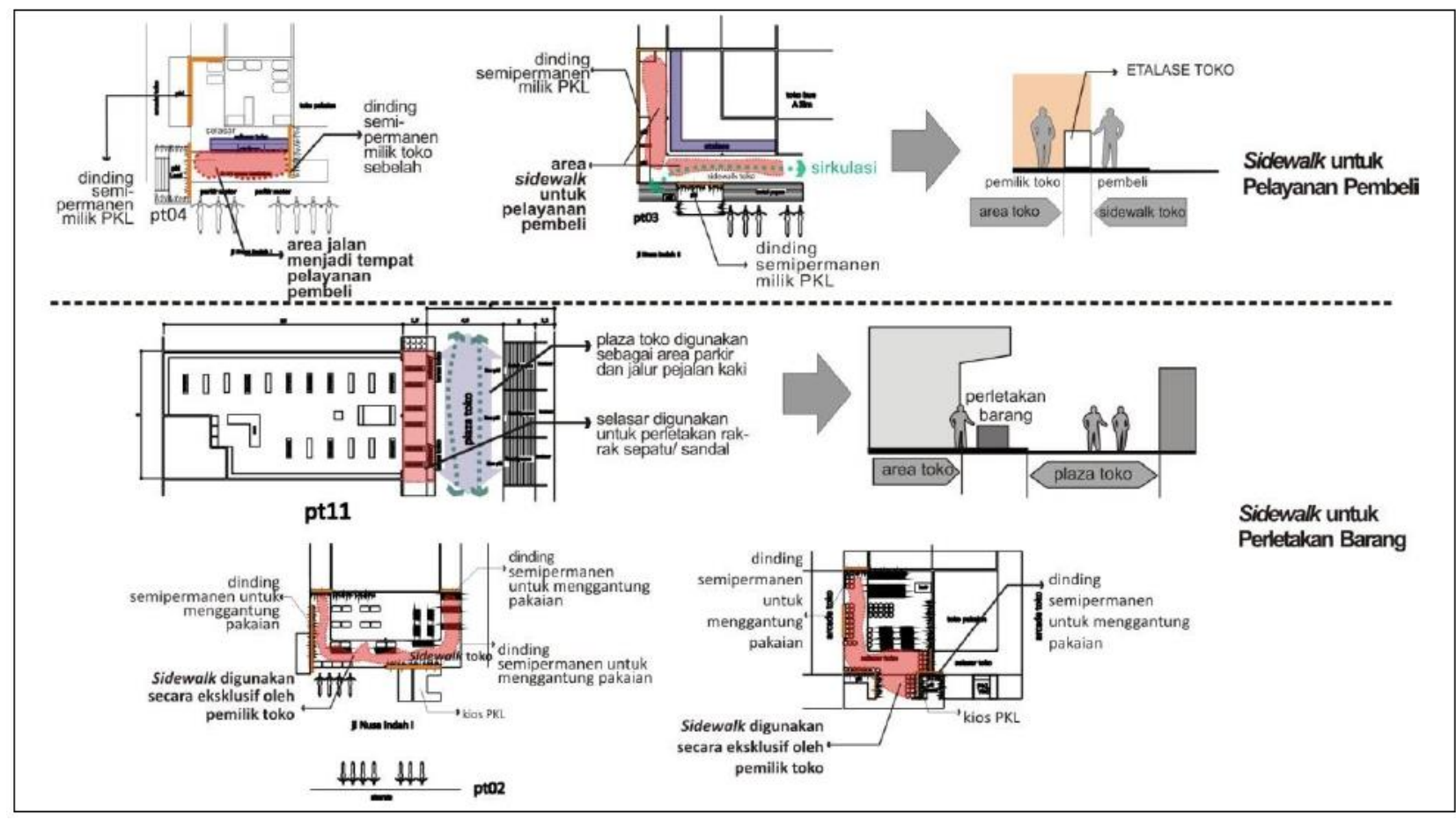

Gambar 3: Berbagai Perletakan Barang di Teritori Pemilik Toko Sumber: Kurniadi (2012) 
Untuk pejalan kaki memiliki teritori formal berupa area sidewalk toko dan trotoar untuk jalur sirkulasi yang merupakan zona publik. Selain untuk sirkulasi, teritori tersebut juga berfungsi untuk memfasilitasi aktivitas window-shopping dan membeli. Sebagian besar sidewalk dan trotoar yang memiliki unsur manifes sebagai jalur sirkulasi pejalan kaki tidak dapat digunakan untuk sirkulasi karena privatisasi yang dilakukan oleh User Group lain. Hal tersebut tersebut menyebabkan keterhubungan antarjalur sirkulasi itu menjadi terpotong-potong dan tidak menerus. Peluang invasi dari pengguna lain menjadi lebih besar dan pejalan kaki tidak memiliki kontrol yang kuat untuk mempertahankan teritori formalnya yaitu jalur berjalan kaki.

Dari analisa yang dilakukan ternyata sebagian besar pemilik toko merasa terganggu dengan keberadaan PKL yang berada di depan toko mereka karena merusak pemandangan, membatasi akses ke toko, dan menyebabkan kebisingan. Upaya kontrol yang dapat dilakukan baru secara pasif dan personal (Kurniadi, Pramitasari, \& Wijono, 2012).

Pemanfaatan ruang terbuka publik sebagai ruang dagang juga menjadi kajian penelitian Sudarisman (2017). Para PKL berjualan di Taman Tegalega Bandung bahkan sampai ruas jalan di sekitarnya dengan menggelar tikar sebagai daerah teritori mereka. Hal ini menimbulkan kemacetan yang luar biasa. Tapi bagi pengunjung hal tersebut tidak menjadi masalah khususnya yang memang bertujuan untuk berbelanja di kawasan tersebut. Justru bagi mereka hal ini menjadi aktivitas sosial mereka dengan berinteraksi dengan para pedagang. Bukan itu saja, mereka juga dapat melakukan aktivitas berolahraga di taman tersebut (Sudarisman, 2017).

Interaksi warga asli Belanda dengan kelompok migran padataman kota menjadi obyek penelitian yang dilakukan oleh Peters (2010). Dari pengamatannya bahwa sedikit sekali terjadi interaksi antar kelompok bidaya tersebut. Hal ini terjadi etnik dan agama pada kelompok migran lebih bersifat kolektif serta adanya pembatasan perilaku pada wanita dalam kelompok tersebut sedangkan warga asli datang secara berpasangan atau hanya sendirian. Batas teritori antar budaya yang berbeda terkadang menguatkan ruang teritori itu sendiri (Peters, 2010).

Aktivitas yang berkelompok ini juga dilakukan oleh penduduk pada beberapa desa di Cina. Dari hasil pengamatan Leng (2016), lebih dari 62\% penduduk Cina memiliki kecenderungan beraktivitas secara berkelompok. Namun berbeda dengan penelitian yang dilakukan oleh Peters (2012) di atas bahwa aktivitas berkelompok disebabkan oleh percampuran budaya melainkan pada kasus ini lebih disebabkan satu budaya yang sama pada satu perdesaan yang cenderung lebih senang melakukan aktivitas mereka secara bersama-sama di ruang terbuka publik (Leng \& Li, 2016). Untuk aktivitas yang dilakukan oleh individu pada latar belakang budaya yang sama maka teritorialitas menjadi hal yang tidak begitu penting.

Pada ruang terbuka yang dimiliki oleh suatu kelompok tertentu seperti perusahaan/kantor maka ruang terbuka dimanfaatkan sebagai ruang pertemuan informal bagi kelompok tertentu sedangkan individu baru yang memasuki ruang terbuka tersebut akan mencari zona/ruang baru yang mereka anggap jarang digunakan. Pola perilaku ini dapat dilihat dari tamu kantor yang harus menunggu pada sebuah bangunan gazebo yang terdapat di pinggir kolam ikan(Hantono, 2013).

Tabel 2. Ruang Personal/Teritori \& Ruang Sosial di Ruang Terbuka Publik

\begin{tabular}{|c|c|c|}
\hline Penulis & Ruang Personal/Teritori & Ruang Sosial \\
\hline Sudarisman (2017) & Pedagang menggelar tikar. & $\begin{array}{lll}\text { - } & \text { Interaksi antara pengunjung dan } \\
& \text { pedagang. } \\
\text { - } & \text { Berolahraga. } & \\
\end{array}$ \\
\hline Leng \& Li (2016) & Hampir tidak ada. & $\begin{array}{l}\text { Aktivitas dilakukan secara bersama-sama } \\
\text { atau berkelompok. }\end{array}$ \\
\hline $\begin{array}{l}\text { Al-Bishawi, } \quad \mathrm{dkk} \\
\text { (2015) }\end{array}$ & $\begin{array}{l}\text { - Teritori dilakukan dengan desain } \\
\text { arsitektur, seperti: posisi pintu, jendela, } \\
\text { dll. } \\
\text { - Pembatasan akses pada ruang terbuka } \\
\text { publik berdasarkan gender. }\end{array}$ & $\begin{array}{l}\text { Hampir tidak ada khususnya antar gender } \\
\text { yang berbeda berdasarkan aturan agama } \\
\text { dan budaya. }\end{array}$ \\
\hline
\end{tabular}




\begin{tabular}{|c|c|c|}
\hline & - $\quad$ Perbedaan waktu penggunaan ruang. & \\
\hline Hantono (2013) & $\begin{array}{l}\text { Pendatang mencari ruang sebagai } \\
\text { teritorialitas mereka. }\end{array}$ & Sebagai ruang pertemuan informal \\
\hline $\begin{array}{l}\text { Kurniadi, } \\
\text { (2012) }\end{array}$ & $\begin{array}{l}\text { - Teritori dengan membuat ruang yang } \\
\text { lebih masif (nyata) seperti kios pada } \\
\text { ruang pasar. } \\
\text { - Meletakkan barang pada titik-titik } \\
\text { lokasi tertentu. }\end{array}$ & $\begin{array}{l}\text { Ruang sosial bagi PKL, pemilik toko, } \\
\text { pejalan kaki, pembeli. }\end{array}$ \\
\hline Peters (2010) & Perbedaan budaya & Antar sesama kelompok atau pasangan \\
\hline
\end{tabular}

Sumber: Hasil Analisis

Berdasarkan hasil pembahasan dari beberapa sumber kajian maka ruang terbuka publik yang memiliki kultur atau budaya yang sama maka teritorialitas bukan menjadi hal yang mutlak. Setiap pengguna bisa bebas berbaur dan menampilkan identitas mereka sebagai makhluk sosial. Mereka dapat beraktivitas seperti berolahraga, berbelanja, bertemu, dan interaksi lainnya tanpa membuat batas teritori yang jelas. Sedangkan pada beberapa latar belakang yang berbeda khususnya kebudayaan maka batasan teritori terbentuk baik yang dibuat sendiri atau mencari ruang teritori yang dianggap aman oleh mereka.

Bentuk ruang teritori tidak harus selalu dalam bentuk ruang fisik saja. Ruang teritori bisa menggunakan benda lain sebagai penanda, tulisan, identitas fisik, atau bahkan bau-bauan. Sebenarnya konsep teritori ini sendiri merupakan konsep yang diadaptasi dari perilaku hewan yaitu berawal dari penelitian pada hewan primata dan vertebrata yang dilakukan oleh Snyder (1984). Perilaku hewan-hewan tersebut dengan mencakar (teritori fisik) atau memberi bau-bauan dari kotoran mereka sendiri (teritori non fisik) sebagai batas wilayah kekuasaan mereka (Snyder \& Catanese, 1984).

\section{KESIMPULAN}

Ruang pribadi (personal space) dan teritori (territory) adalah ruang privasi manusia dalam aktualisasi karakteristik manusia sebagai makhluk individu. Walaupun sama namun bedanya adalah ruang pribadi merupakan ruang maya yang berada di sekeliling manusia sedangkan teritori dibentuk sesuai dengan kondisi tertentu. Teritori ini sendiri dapat diusik oleh individu lain sehingga pertahanan manusia ini sifatnya tidak masif.

Ada 2 (dua) hal yang mempengaruhi teritori di dalam ruang terbuka publik. Pertama, ekonomi. Ruang publik yang dijadikan ruang dagang maka tingkat kualitas publiknya akan semakin menurun. Hal ini disebabkan adanya teritori yang dilakukan oleh para pedagang dalam mempertahankan tujuan mereka dalam ruang tersebut. Penurunan kualitas ini akan menjadikan ruang publik menjadi ruang privat yang biasanya cukup mengganggu aktivitas lingkungannya.Kedua, budaya.Kultur yang sama pada satu ruang publik menjadikan ruang personal bagi setiap individu semakin mengecil. Hal ini menjadikan ruang teritori semakin tidak dibutuhkan dalam aktivitas mereka di dalam kelompok yang sama.

Hal demikian menunjukkan bahwa keprivasian bagi manusia tetap menjadi hal utama bagi mereka dalam memanfaatkan ruang terbuka publik. Bahkan pada suatu kebudayaan dan agama tertentu sikap saling menjaga jarak untuk menghindar dari interaksi terutama antar kaum perempuan dengan kaum laki-laki merupakan bentuk pertahanan diri mereka terhadap keprivasian. 


\section{DAFTAR REFERENSI}

Al-Bishawi, M., Ghadban, S., \& Jørgensen, K. (2015). Women's Behaviour In Public Spaces And The Influence Of Privacy As A Cultural Value: The Case Of Nablus, Palestine. Urban Studies, 54(7), 1559-1577. https://doi.org/10.1177/0042098015620519

Hadi, S. (1991). Analisis Butir Untuk Instrumen (1st ed.). Yogyakarta: Andi Offset.

Hakim, R., \& Utomo, H. (2003). Komponen Perancangan Arsitektur Lansekap: Prinsip-Unsur dan Aplikasi Desain. Jakarta: Penerbit Bumi Aksara.

Halim, D. (2005). Psikologi Arsitektur Pengantar Kajian Lintas Disiplin. Jakarta: Grasindo.

Hantono, D. (2013). Pengaruh Ruang Terbuka Terhadap Kinerja Pegawai. Nalars, 12(2), 1-12. https://doi.org/10.24853/nalars.12.2.\%25p

Haryadi, \& Setiawan, B. (2014). Arsitektur, Lingkungan dan Prilaku: Pengantar ke Teori, Metodologi dan Aplikasi (2nd ed.). Yogyakarta: Gadjah Mada University Press.

Kurniadi, F., Pramitasari, D., \& Wijono, D. (2012). Konsep Perilaku Teritorialitas di Kawasan Pasar Sudirman Pontianak. Vokasi, 8(3), 197-208. Retrieved from http://riset.polnep.ac.id/bo/upload/penelitian/penerbitan_jurnal/08-Fery ganti6.pdf

Laurens, J. M. (2004). Arsitektur dan Perilaku Manusia. (Diane Novita, Ed.). Jakarta: PT. Grasindo.

Leng, H., \& Li, T. (2016). Research on Public Open Space of Rural Areas in Severe Cold Regions Based on Survey of Residents on the Behavioral Activity. In Procedia Engineering (pp. 327334). Elsevier. https://doi.org/10.1016/j.proeng.2016.06.400

Peters, K. (2010). Being Together in Urban Parks: Connecting Public Space, Leisure, and Diversity. Leisure Sciences, 32(5), 418-433. https://doi.org/10.1080/01490400.2010.510987

Purwantiasning, A. W. (2017). Optimalisasi Fungsi Ruang Terbuka Hijau Dengan Melihat Pola Sebaran Pengunjung Studi Kasus: Taman Tabebuya, Jagakarsa. Nature, 4(2), 121-127. https://doi.org/10.24252/nature.v4i2a4

Sarwono, S. W. (1995). Psikologi Lingkungan. Jakarta: PT. Grasindo.

Snyder, J. C., \& Catanese, A. J. (1984). Pengantar Arsitektur. (Hendro Sangkayo, Ed.). Jakarta: Penerbit Erlangga.

Sudarisman, I. (2017). Kajian Pedagang Kaki Lima Di Taman Tegalega, Bandung, Jawa Barat. Arsir , 1(2), 161-174. Retrieved from http://jurnal.um-palembang.ac.id/arsir/article/view/867/769 https://winnerfirmansyah.wordpress.com/2010/04/11/privasi-dan-teritorialmanusia/,akses Septem-ber 2018. http://atemalem.com/gaya-baru-malam-selatan/; Diakses pada Februari 2018 